\title{
Regulation of the Expression of Epidermal Keratinocyte Proliferation and Differentiation by Vitamin A Analogs*
}

\author{
C. L. Marcelo and K. C. Madison \\ University of Michigan Medical School, Dermatology, Box 056, Kresge I, R-6558, Ann Arbor, Michigan 48109, USA
}

\begin{abstract}
Summary. A number of vitamin A analogs (retinoids) were used to manipulate the growth of epidermal keratinocytes in culture. The retinoids used were the TMMP analog of ethyl retinoate (Ro 10-9359), 13-cis retinoic acid, all trans retinoic acid and retinol (trans). These were added to primary neonatal mouse epidermal keratinocyte cultures that proliferate, stratify, and differentiate over $2-3$ weeks. $\left[{ }^{3} \mathrm{H}\right] \mathrm{Tdr}$ labeling technics were used to quantitate proliferation. A histologic stain, and a four buffer protein extraction protocol, used in conjunction with polyacrylamide gel electrophoresis and fluorographic technics, were used to assess the differentiation of the cultures. Our results showed that all of the vitamin A analogs we tested inhibited keratinocyte proliferation. Quantitation of specific differentiation proteins showed that Ro 109359 and 13-cis retinoic acid partially inhibited the differentiation of the cultures. The Ro 10-9359 retinoid was unusual in that it increased the synthesis of keratohyalin granule-related proteins. These studies showed that inhibition of basal cell proliferation did not result in the obligatory expression of cell differentiation and that at least one of the events that is a part of epidermal keratinocyte differentiation can be separately controlled.
\end{abstract}

Key words: Vitamin A analogs - Epidermal keratinocyte - Keratins - Keratohyalin granule - Cell envelopes

\section{Introduction}

Epidermal keratinocytes proliferate and differentiate in a complex, multi-layered pattern. These processes are balanced so that new basal cells are formed as the

\footnotetext{
* These data, in part, were presented at the Proceedings of the International Dermatology Symposium in Berlin, FRG, on October 13,1980 [33]

Send offprint requests to: C. L. Marcelo (address see above)
}

totally differentiated cornified cells are shed from the surface of the skin [1]. In hyperproliferative and keratinizing skin disorders, an imbalance of epidermal differentiation and proliferation occurs [2].

Vitamin A controls epithelial differentiation [3-11] and proliferation [12-15] in a number of in vitro model systems. Retinoic acid has been shown to stimulate adult guinea pig keratinocyte proliferation during the first $24-60 \mathrm{~h}$ of culture [12-14], possibly by altering the plating efficiency and cell surface properties of the freshly trypsinized cells. After this initial effect, retinoic acid appears to affect the differentiation of the keratinocytes, primarily by influencing the attachement/ detachment ratio of the keratinocytes [9-11] and by decreasing keratin [7] and cell envelope formation [8]. Retinoids (vitamin A analogs) other than retinoic acid, however, appear to have different effects on in vitro keratinocytes [15].

Two vitamin A analogs, Ro 10-9359 (Tigason) and 13-cis retinoic acid (Accutane) have been used successfully in the treatment of cutaneous disorders [16]. We manipulated the growth of in vitro epidermal keratinocytes using primarily these two retinoids to study the relative expression of epidermal proliferation and differentiation.

The primary cultures used in these investigations start as a monolayer of slowly proliferating neonatal mouse basal cells [17]. The cells stratify and differentiate over $2-3$ weeks. The resulting culture is a good in vitro model of the epidermis, i.e., a proliferating basal cell population producing layers of more differentiated, shedding keratinocytes [17]. The differentiation of the cultures is assessed, on a gross morphologic level, by use of histochemical stains [17]. Recently, we described a technic that quantitates the proteins that are synthesized and processed during keratinocyte differentiation, i.e., the keratohyalin granule-releated proteins, the non-covalent and disulfide cross-linked keratins and cell envelopes [18]. 
Our results showed that all vitamin A analogs tested inhibited both keratinocyte proliferation and differentiation. In addition, these studies indicate that several of the events occurring during keratinocyte differentiation can be separately controlled.

\section{Materials and Methods}

\section{Reagents and Animals}

Neonatal mice were obtained from a BALB/c colony housed in the University of Michigan Medical School Dermatology Department. All tissue culture medium products were obtained from Flow Laboratories (Rockville, MD, USA). Chemicals for the Kreyberg stain were obtained from Matheson Gas Products (East Rutherford, NJ, USA); saffron (Chroma-Gesellschaft) is from the Roboz Surgical Co. (Washington, DC, USA). $\left[{ }^{3} \mathrm{H}\right] \mathrm{Td} \mathbf{r}(60-85 \mathrm{Ci} / \mathrm{mmol})$ and EN $^{3}$ HANCE were bought from New England Nuclear (Boston, MA, USA). L- $\left[2,5-{ }^{3} \mathrm{H}\right]$ histidine $\left(\left[{ }^{3} \mathrm{H}\right] \mathrm{his} ; 44 \mathrm{Ci} / \mathrm{mmol}\right)$ was obtained from Radiochemical Centre, Amersham, UK. Ultrapure urea was purchased from Schwarz-Mann (Spring Valley, NY, USA). Molecular weight (MW) protein standards were purchased from Pharmacia Fine Chemicals (Piscataway, NJ, USA). All materials for electrophoresis and dodecylsulfate (SDS) were from Bio-Rad Laboratories (Richmond, CA, USA). Phenylmethylsulfonyl fluoride (PMSF) was obtained from Calbiochem (San Diego, CA, USA). Ro 10-9359 [trimethylmethoxyphenyl (TMMP) analog of retinoic acid ethyl ester (etretinate); $\mathrm{MW}=354$ ], and 13-cis retinoic acid (Ro 4-3780) were generous gifts from Hoffmann-La Roche (Nutley, NJ, USA). All-trans vitamin A acid (retinoic acid) and vitamin A alcohol (retinol, trans) were purchased from Sigma (St. Louis, MO, USA). X-Omat X-ray film was obtained from Eastman Kodak (Rochester, NY, USA). Corning plastic products and Costar 24 well plates were used for cell culture preparation and growth.

\section{Keratinocyte Cultures}

The procedure for isolating neonatal mouse basal cells from full thickness skin was previously described [17]. Viable basal cells are plated in medium 199 plus $13 \%$ FBS containing $50 \mathrm{IU} / \mathrm{ml}$ penicillin and $50 \mu \mathrm{g} / \mathrm{ml}$ streptomycin at a density of $2 \times 10^{5}$ cells per $\mathrm{cm}^{2}$. The cultures are grown in $5 \% \mathrm{CO}_{2}$ in air, humidified gassing, at $32^{\circ} \mathrm{C}$ in either 35 or $60 \mathrm{~mm}$ Petri dishes. The medium is changed every second day.

\section{Addition of Vitamin A Analogs}

All vitamin A analogs were dissolved in DMSO (Sigma) and kept in small volumes with minimal to no airspace at $-30^{\circ} \mathrm{C}$ or $-70^{\circ} \mathrm{C}$ until used. The retinoids were always handled in dimmed light. The analogs were added to the basal cell monolayers on day 3 after plating and with each subsequent medium change. $0.2 \% \mathrm{DMSO}$ in growth medium was used as the vehicle control.

\section{$\left.\Gamma^{3} H\right] T d r$ Labeling of DNA and Autoradiography}

Keratinocyte cultures are terminally pulse labeled for $6 \mathrm{~h}$ with $1 \mu \mathrm{Ci} / \mathrm{ml}\left[{ }^{3} \mathrm{H}\right] \mathrm{Tdr}$. DNA was extracted, assayed and counted as previously described [17]. The results are expressed as cpm of $\left[{ }^{3} \mathrm{H}\right] \mathrm{Tdr}$ label per $\mu \mathrm{g}$ DNA. The data are presented as percent of the DMSO vehicle control (retinoid treated culture $\mathrm{cpm} / \mu \mathrm{g}$ DNA divided by $0.2 \%$ DMSO control cpm $/ \mu \mathrm{g} D \mathrm{DNA} \times 100$ ).

For autoradiography, keratinocytes grown on round Lux cover slips were processed as previously described [17].

\section{Transmission Electron Microscopy and Phase Microscopy}

The keratinocytes are grown on Lux $15 \mathrm{~mm}$ round cover slips. At the appropriate times, the cultures were fixed and processed as previously described [17]. The sections were examined in a Philips 300 electron microscope at $60 \mathrm{kV}$. For phase microscopy photography, the cultures are photographed while growing in complete medium.

\section{Labeling of Epidermal Keratinocytes with Tritiated Histidine}

$60 \mathrm{~mm}$ Petri dishes were pulse labeled for $2 \mathrm{~h}$ at $37^{\circ} \mathrm{C}$ with $10 \mu \mathrm{Ci} / \mathrm{ml}$ $\left[{ }^{3} \mathrm{H}\right]$ his in M-199 diluted 1:5 with PBS pH 7.0 on each of 3 days $(2,6$ and 10 days after adding the retinoids). After a $2 \mathrm{~h}$ cold chase with growth medium at $32^{\circ} \mathrm{C}$, the cultures were washed twice with cold PBS containing $5 \mu \mathrm{g} / \mathrm{ml}$ PMSF, a protease inhibitor. The cultures were then extracted or stored at $-70^{\circ} \mathrm{C}$ until extraction.

\section{Extraction of Epidermal Keratinocyte Proteins}

The cultures were serially extracted using four buffers to yield six fractions as previously described [18]. These are in order of extraction:

Keratohyalin Granule (KG) Fractions (Macroaggregates and High Salt Soluble Proteins). The cells from 10 cultures are scraped with $1 \mathrm{M} \mathrm{KPO}_{4}$ buffer, $\mathrm{pH} 7.0$, containing $0.22 \mathrm{M}$ l-histidine plus $10 \mu \mathrm{g} / \mathrm{ml}$ PMSF. After sonication and incubation at $37^{\circ} \mathrm{C}$ for $30 \mathrm{~min}$ with shaking, the samples are centrifuged at $50,000 \times g(26,000 \mathrm{rpm}$, Beckman type rotor) for $30 \mathrm{~min}$. The supernate is dialyzed against distilled water containing PMSF for several days in the cold. A precipitate containing keratohyalin granule macroaggregates is formed, leaving a supernate containing high salt extractable cell proteins and any serum contaminants, i.e., albumin [18].

SDS Soluble Proteins. The cell residue is further extracted with $2 \mathrm{ml}$ $0.05 \mathrm{M} \mathrm{NaPO}_{4}$ buffer, $\mathrm{pH} 7.0$, containing $1 \%$ SDS (w/v) plus $5 \mu \mathrm{g} / \mathrm{ml}$ $\mathrm{PMSF}$ at room temperature for $30 \mathrm{~min}$. This step extracts the soluble proteins from non-enveloped nucleated cells [19].

Non-Cross-Linked Fibrous Proteins. The detergent insoluble residue is then extracted using $4 \mathrm{M}$ urea in $0.05 \mathrm{M} \mathrm{NaPO}_{4}$ buffer plus $10 \mu \mathrm{g} / \mathrm{ml} \mathrm{PMSF}, \mathrm{pH} 7.0$, at room temperature for $16 \mathrm{~h}$. The supernate contains, in addition to minor small MW proteins, non-disulfide cross-linked keratin polypeptides.

Covalently Cross-Linked Fibrous Proteins. The $4 \mathrm{M}$ urea insoluble proteins are further extracted using $2 \mathrm{ml} 0.05 \mathrm{M} \mathrm{NaPO}_{4}$ buffer, $\mathrm{pH} 7.0$, containing $8 \mathrm{M}$ urea, $0.1 \mathrm{M} 2$-mercapto ethanol and $1 \mathrm{mM}$ DL-dithiothreitol plus $10 \mu \mathrm{g} / \mathrm{ml}$ PMSF.

Cell Envelope Proteins. The remaining pellet consists of cell envelopes [18].

All the supernates are dialyzed at $4^{\circ} \mathrm{C}$ against distilled water containing PMSF and then lyophylized. After being resuspended (see legend to Fig. 4), $10 \mu 1$ triplicate aliquots of each fraction are assayed by a modified Lowry technique for protein concentration using serum albumin as a standard [18]. The radioactivity per fraction is determined by liquid scintillation counting. Aliquots containing $25-150 \mu \mathrm{g}$ protein are analyzed using SDS polyacrylamide gel electrophoresis (SDS-PAGE).

\section{Sodium Dodecyl Sulfate Polyacrylamide Gel Electrophoresis and Fluorography}

SDS-PAGE was performed according to the method of Laemmli at pH 8.8 [20], as previously described by us [18]. 


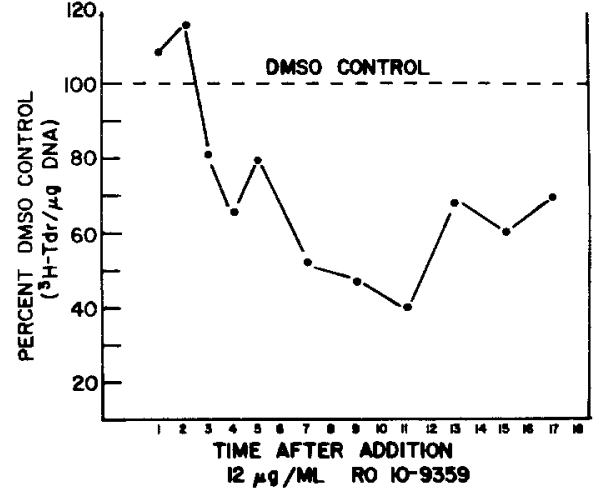

Fig. 1. The effect of $12 \mu \mathrm{g} / \mathrm{ml}$ Ro $10-9359$ on epidermal keratinocyte proliferation. One hundred and forty $35 \mathrm{~mm}$ Petri dishes of primary cultures were prepared. Quadruplicate Petri dishes, of both retinoid treated and DMSO-control and control, were pulse labeled on each day. The retinoid and DMSO vehicle were added day 3 after plating; there was no change in the retinoid treated culture acid soluble ${ }^{3} \mathrm{H}$-labeled nucleotides and nucleotides, indicating that transport of $\left[{ }^{3} \mathrm{H}\right] \mathrm{Tdr}$ into the cell was probably not affected. The control and DMSO control $\left[{ }^{3} \mathrm{H}\right] \mathrm{Tdr} / \mu \mathrm{g}$ values were identical. The data is presented as percentage control. Since this was one large experiment, no SD or SEM can be presented. However, the quadruplicate values for each of the controls, and Ro-9359 treated cultures were within $10 \%$ of the average value

Table 1. Comparison of the effect of four retinoids on keratinocyte proliferation

\begin{tabular}{llllll}
\hline & $\begin{array}{l}\text { Percentage } \\
\text { inhibition }\end{array}$ & & & $\begin{array}{l}\text { Percentage } \\
\text { labeled cells }\end{array}$ \\
\hline $\begin{array}{l}\text { Days after addition } \\
\text { Retionid }\end{array}$ & 3 & 5 & 10 & 12 & 10 \\
Ro 10-9359 & $20 \%$ & $19 \%$ & $19 \%$ & $45 \%$ & $1.0 \% \pm 0.1$ \\
All-trans RA & $(2)$ & $(2)$ & $(3)$ & $(2)$ & \\
13-cis RA & $13 \%$ & $68 \%$ & $67 \%$ & $49 \%$ & $0.4 \% \pm 0.1$ \\
& $(8)$ & $(6)$ & $(7)$ & $(2)$ & \\
Retinol & $32 \%$ & $39 \%$ & $42 \%$ & $71 \%$ & - \\
& $(8)$ & $(7)$ & $(6)$ & $(2)$ & \\
Control (no retinoid) & - & $53 \%$ & - & $52 \%$ & - \\
\hline
\end{tabular}

Number in parenthesis is the $n$ number

Retinol at $12 \mu \mathrm{g} / \mathrm{ml}$ was cytotoxic, i.e., monolayer was destroyed

\section{Results}

Effect of Ro 10-9359

on Epidermal Keratinocyte Proliferation

Time Course Study. A 17 day study is presented in Fig. 1. Inhibition of $\left[{ }^{3} \mathrm{H}\right] \mathrm{Tdr}$ incorporation into DNA was caused by $12 \mu \mathrm{g} / \mathrm{ml}(34 \mu \mathrm{M})$ of Ro $10-9359$ after 4-5 days; this inhibition was most pronounced 7-11 days after adding the drug (50-60\% inhibition). The drug effect decreased on days $14-17$ for the $12 \mu \mathrm{g} / \mathrm{ml}$ dose. At no time was stimulation of proliferation seen.
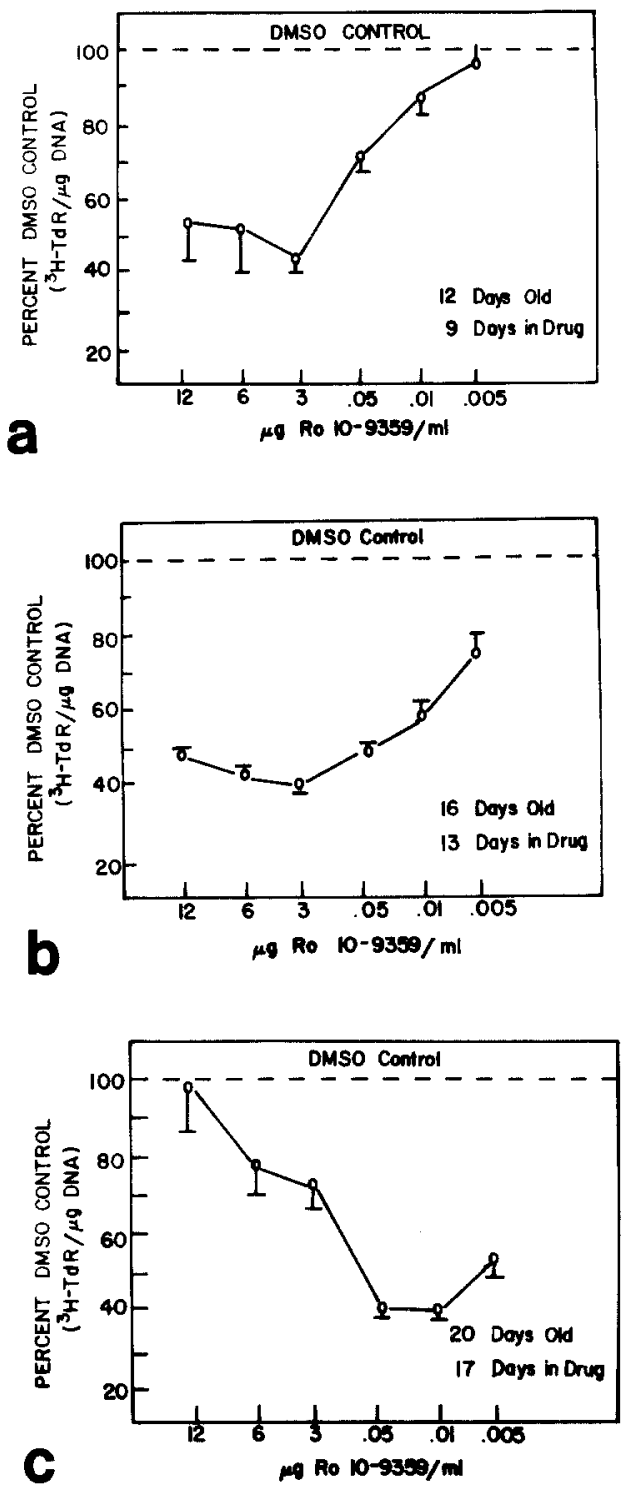

Fig. 2a-c. Ro 10-9359 dose response curve. The doses used were: $12 \mu \mathrm{g} / \mathrm{ml}=34 \mu \mathrm{M} ; 6 \mu \mathrm{g} / \mathrm{ml}=17 \mu \mathrm{M} ; 3 \mu \mathrm{g} / \mathrm{ml}=8.5 \mu \mathrm{M} ; 0.05 \mu \mathrm{g} / \mathrm{ml}$ $=140 \mathrm{nM} ; 0.01 \mu \mathrm{g} / \mathrm{ml}=28 \mathrm{nM} ; 0.005 \mu \mathrm{g} / \mathrm{ml}=14 \mathrm{nM}$. Retinoid in a final vehicle concentration of $0.2 \%$ DMSO was added to be cultures on day 3 after plating. The cultures were terminally pulse labeled for $6 \mathrm{~h}$ with $1 \mu \mathrm{Ci} / \mathrm{ml}\left[{ }^{3} \mathrm{H}\right] \mathrm{Tdr}$ on: a 12 days after plating; $P \leq 0.05$ $=$ doses $12,6,3,0.05$. b 16 days after plating; $P \leq 0.05=$ doses 12,6 , $3,0.05,0.01$. c 20 days after plating; $P \leq 0.05=$ doses $3,0.05,0.01$, 0.005 . $n=3-8$; quadruplicate Petri dishes/experiment. Statistical analysis $=$ Student's $t$-test for paired data

The retinoid did not change the amount of total protein per culture, and the total DNA in the treated cultures was equal to or slightly greater than the control value (data not presented). Autoradiography showed that Ro 10-9359 significantly decreased the percentage of labeled cells (part of Table 1).

Dose Response Study. Dose response studies using $12 \mu \mathrm{g} / \mathrm{ml}(34 \mu \mathrm{M})$ to $0.005 \mu \mathrm{g} / \mathrm{ml}(14 \mathrm{nM})$ concen- 



Fig. 3a-f. Micrographs of retinoid treated cultures. a Phase micrograph of 10 day control cultures. Solid arrow marks differentiated cell layers that stain red with the Kreyberg stain. b Phase micrograph of the $0.2 \%$ DMSO control. Solid arrow marks differentiated cell layers that stain red with the Kreyberg stain. c Phase micrograph of a $12 \mu \mathrm{g} / \mathrm{ml}$ 13-cis retinoic acid treated culture ( 7 days after adding the retinoid). There are few or no differentiating cell layers, although stratification is seen. d Phase micrograph of a culture treated with $12 \mu \mathrm{g} / \mathrm{ml}$ all-trans retinoic acid 7 days after adding the drug. No differentiating cell layers are seen. e Phase micrography of a culture treated with $12 \mu \mathrm{g} / \mathrm{ml}$ Ro $10-9359$ for 7 days. Little or no differentiation is seen. This retinoid induced vacuole formation (arrow). (a-e Bar $=50 \mu \mathrm{m}, \times 240)$. f Electron micrography of a $12 \mu \mathrm{g} / \mathrm{ml}$ Ro 10-9359-treated culture. The micrograph is a $\times 36,400$ magnification of the membrane lined vacuoles (arrow). Bar $=0.27 \mu \mathrm{m}$

trations of Ro 10-9359 are presented in Fig. $2 \mathrm{a}-\mathrm{c}$. The 12,6 and $3 \mu \mathrm{g} / \mathrm{ml}$ doses inhibited the proliferation of the cultures after 9 days by $40-50 \%$ (Fig. 2 a). The $0.05 \mu \mathrm{g} / \mathrm{ml}$ dose inhibited approximately $25 \%$, while the two lowest doses had no statistically significant effect.
Figure $2 \mathrm{~b}$ presents the dose response after 13 days of growth in Ro 10-9359. The three lowest doses now inhibited $20-50 \%$ while the three higher doses inhibited by $50 \%$ epidermal keratinocyte proliferation.

In Fig. 2c, the dose response, seen on day 17, is graphed. Two effects were seen: first, the $0.05,0.01$ and 


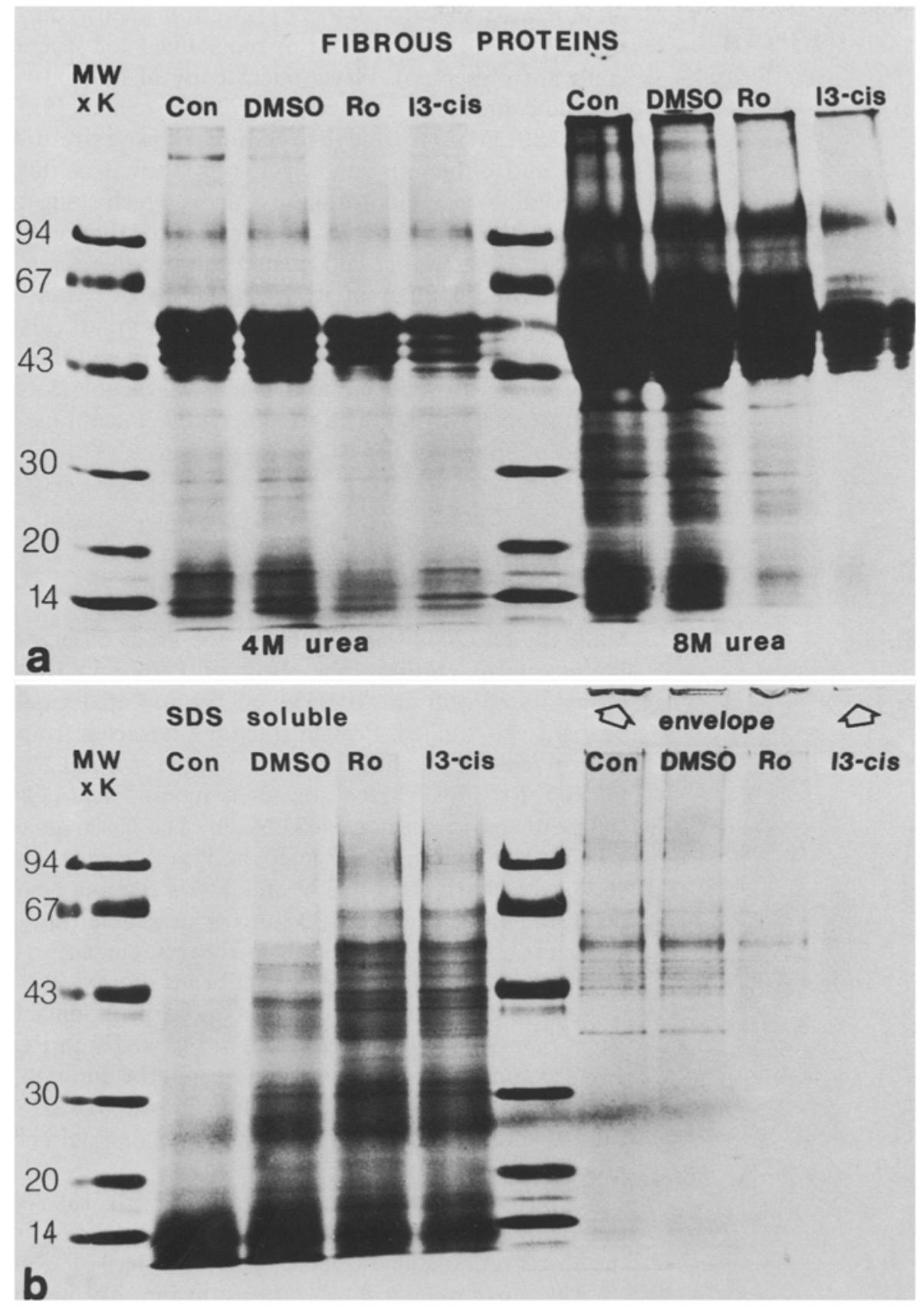

Fig. 4a and b. Coomassie blue stained PAGE of the protein fractions of 12-day-old retinoid treated cultures. a Fibrous proteins: $4 \mathrm{M}$ urea soluble (non-covalently cross-linked) and $8 \mathrm{M}$ urea and reducing agents extractable (covalently cross-linked) keratin proteins. b SDS soluble, viable cell proteins. Cell envelope fractions which do not enter the gels (arrow). The lyophilized and residue fractions were resuspended in: $\mathrm{KG}$ macroaggregated and viable cell proteins $=0.05 \mathrm{M} \mathrm{NaPO}_{4}, \mathrm{pH} 7.0$, containing $1 \%$ SDS and $100 \mathrm{mM}$ 2-mecaptoethanol. $4 \mathrm{M}$ and $8 \mathrm{M}$ urea extractable keratins and cell envelopes $=0.05 \mathrm{M} \mathrm{NaPO}_{4}, \mathrm{pH} 7.0$, $8 \mathrm{M}$ urea and $100 \mathrm{mM} \mathrm{2-mercapto-}$ ethanol and $1 \mathrm{mM}$ DL-dithiothreitol and $1 \%$ SDS. An equivalent portion from a Petri dish was put into each lane. For example, $1 / 4$ dish of control, DSMO control, Ro 10-9359 and 13-cis retinoic acid were used to run the $4 \mathrm{M}$ urea fraction (panel a). In this way an acurate comparison among the cultures can be made [18]
$0.005 \mu \mathrm{g} / \mathrm{ml}$ doses became strongly inhibitory $(50-$ $60 \%$; second, the 3 and $6 \mu \mathrm{g} / \mathrm{ml}$ doses showed partial loss of inhibition, and the $12 \mu \mathrm{g} / \mathrm{ml}$ dose completely lost its inhibitory effect.

\section{Comparisons of the Effect of Four Retinoids on Epidermal Keratinocyte Proliferation}

The effect of $12 \mu \mathrm{g} / \mathrm{ml} 13$-cis retinoic acid, of all transretinoic acid or of retinol was compared with that of the Ro 10-9359 analog. These and the autoradiography data are presented in Table 1. All trans-retinoic acid, 13-cis retinoic acid and retinol were more potent inhibitors of keratinocyte proliferation than Ro 109359. Retinol at $12 \mu \mathrm{g} / \mathrm{ml}$ had a cytotoxic effect, i.e., a marked decrease in cellular DNA and protein (data not shown).

\section{Morphology of Retinoid Treated Cultures}

Histologic (Kreyberg [17]) staining of retinoid treated cultures showed that all trans-retinoic acid, 13-cis 

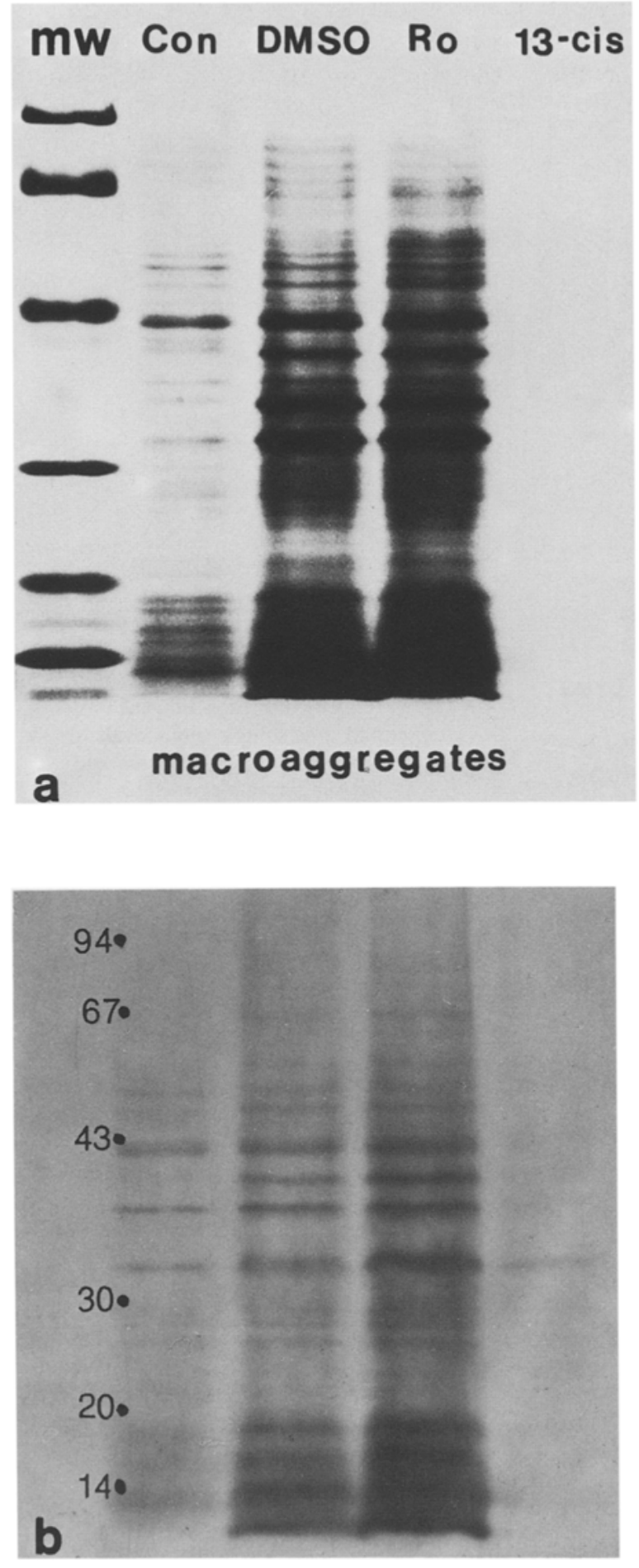

Fig. 5a and b. Coomassie blue stained gels and autoradiogram of macroaggregated keratohyalin-granule related proteins. a Coomassie stained PAGE; $\mathbf{b}$ autoradiogram of PAGE. 13-cis retinoic acid almost absolutely inhibited the synthesis, while Ro 10-9359 stimulated the synthesis, of these proteins. The stained gel and autoradiogram are of 12-day-old cultures. Since the day 2 and day 7 data were similar to the results obtained on day 12 , only the day 12 data are shown retinoic acid and Ro $10-9359(12 \mu \mathrm{g} / \mathrm{ml})$ greatly decreased $(>80 \%)$ the amount of red stained cell layers (data not presented). Phase microscopy of living 10day-old cultures is presented in Fig. 3. The control (3a) and $0.2 \%$ DMSO treated $(3 \mathrm{~b})$ cultures showed stratification and differentiation which was normal at this time point. Arrows indicate those areas which stained red when the Kreyberg technique was used. Figure 3c shows a 13 -cis retinoic acid treated culture; there were very few or no differentiating cell layers. All transretinoic acid (3d) and Ro 10-9359 (3e) also markedly reduced the differentiation of the cultures. In addition, $12 \mu \mathrm{g} / \mathrm{ml}$ Ro 10-9359 induced extensive vacuole formation (open arrow). The vacuoles were membranebound as shown in Fig. $3 f$ (arrow).

\section{Effect of Vitamin A Analogs on Epidermal Keratinocyte Proteins}

Since the retinoids were inhibiting the gross differentiation of the cultures, the effect of $12 \mu \mathrm{g} / \mathrm{ml} 13$-cis retinoic acid and Ro 10-9359 on specific epidermal proteins was studied. Protein fractions extracted from control cultures and from cells treated with $0.2 \%$ DMSO, Ro 10-9359 (Ro), or 13-cis retinoic acid (13cis) were analyzed using SDS-PAGE. The Coomassie blue stained gels are presented in Fig. 4. Figure 4a shows that both Ro 10-9359 and 13-cis retinoic acid decreased the amount of $4 \mathrm{M}$ urea extractable (noncovalently cross-linked) and $8 \mathrm{M}+$ reducing agent extractable (covalently cross-linked) fibrous proteins (keratins). 13-cis retinoic acid had a more pronounced effect than Ro 10-9359. As shown in Fig. 4b, both Ro 10-9359 and 13-cis retinoic acid increased the amounts (and synthesis, autoradiograms not shown) of SDS soluble viable cell proteins. This indicated that neither retinoid was cytotoxic.

Cell envelope proteins do not enter the gels [18]. As the arrow indicates, less envelope protein was seen in the 13-cis retinoic acid treated cultured (Fig. 4b).

The macroaggregated keratohyalin proteins (Fig. 5a) were increased by $0.2 \%$ DMSO. Ro $10-9359$ further increased the amount of protein in this fraction while 13-cis retinoic acid decreased these proteins to levels below those present in control cultues (no DMSO).

As seen in Fig. 5b, Ro 10-9359 treated cultures showed increased macroaggregated keratohyalin granule protein synthesis above the $0.2 \%$ DMSO value. 13-cis retinoic acid treated cultures, which also were exposed to the $0.2 \%$ DMSO vehicle, showed little or no incorporation of $\left[{ }^{3} \mathrm{H}\right]$ his into this fraction.

No difference was noted between DMSO treated and Ro 10-9359 treated culture soluble keratohyalin 
granule proteins. 13-cis retinoic acid also decreased the amount of protein in this fraction (data not presented).

\section{Discussion}

The control of growth in many cell types is mediated by the cessation of cell proliferation with subsequent expression of the differentiation process [21,22]. This same reciprocal relationship between proliferation and differentiation may exist in the epidermis. If these two keratinocyte functions were inversely expressed, then increased cellular proliferation would result in decreased differentiation, and inhibition of proliferation would induce the synthesis of keratohyalin granules, keratins, cell envelopes and other differentiationrelated proteins.

The experimental results presented here, however, show that keratinocyte proliferation and differentiation are not always inversely expressed. All the retinoids used in these studies arrested, to some extent, keratinocyte proliferation, possibly by action in the $G_{1}$ phase of the cell cycle $[24,25]$. These retinoids also inhibited the normal pattern of differentiation usually seen in these cultures. This was not simply a cytotoxic effect since keratinocyte cultures grown in Ro 10-9359 (the most extensively studied retinoid) remained viable. This was demonstrated by the fact that Ro 10-9359 treated cells retained the capacity to proliferate as shown by the eventual adjustment (refractoriness?) of the cells to the retinoid, and by the increase in the amount of viable cell (SDS soluble) and macroaggregated keratohyalin granule proteins.

All the vitamin A analogs studied inhibited epidermal keratinocyte differentiation when this function was assessed on a gross level by the Kreyberg histologic stain. This was not surprising since at least one retinoid, the aromatic Ro 10-9359, has been reported to decrease markedly the horny layer as well as the number of tonofilaments and desmosomes of guinea pigs fed this retinoid [6]. A detailed analysis of proteins specific for epidermal differentiation was then performed on the Ro 10-9359 and 13-cis retinoic acid treated cultures.

To appreciate fully the retinoid effect, the usual differentiation pattern of these cells should be understood. The epidermal keratinocyte cultures start as basal cell monolayers. The cells contain small amounts of both non-covalently and disulfide cross-linked keratin proteins, and of cell envelopes [18]. Fifty to sixty percent of the total proteins in the cultures is extractable by SDS buffers, indicating that the monolayer consists mostly of viable, nucleated cells. As the cultures stratify (day 4) and become fully differentiated (day $7-8$ ), the basal cells are overlaid by $6-8$ layers of cells undergoing differentiation which contain in- creased amounts of keratohyalin granule, and keratin proteins, and cell envelopes [17, 18]. As cultures totally differentiate, the percentage of SDS soluble protein lessens, i.e., becomes $20-30 \%$ of the total protein, although the absolute amount of protein in this fraction decreases by only a small amount. The keratin and cell envelope proteins are $60 \%$ and $10-12 \%$, respectively, of the total protein in these cultures [18]. The upper cell layers slough off the fully stratified, mature cultures so that the total protein and DNA in the cultures stay at a steady-state level after approximately 1 week of growth [17].

Protein analysis data suggested that as 13-cis retinoic acid arrested basal cell proliferation, the production of cells capable of differentiating also stopped. A 10-12 day old culture grown in medium containing 13-cis retinoic acid had the protein profile of a younger, less differentiated culture. 13-cis retinoic acid was a very potent inhibitor of keratin protein and cell envelope formation, as has been reported for retinyl acetate by Fuchs and Green [27] and of keratohyalin granule protein synthesis. When a 10 -day-old retinoid treated culture was compared with its control, the cells contained and synthesized larger amounts of SDS soluble protein. This showed that the cultures were viable, since cytoxicity decreases the amount of protein in the SDS fraction [18] and cell death stimulates epidermal keratinocyte differentiation [26]. 13-cis retinoic acid almost completely stopped another differentiation function: the synthesis of keratohyalin granule macroaggregated proteins (Fig. 5).

Ro 10-9359 was the least potent inhibitor of epidermal keratinocyte proliferation. This retinoid significantly decreased culture stratification, and the amount of non-covalently and disulfide cross-linked keratin proteins. An increase in the percentage of SDS soluble protein was also induced by this retinoid. The Ro 10-9359 analog differed from 13-cis retinoic acid in that it increased the amount of protein present in the keratohyalin granule macroaggregated fraction. There is no obvious explanation for this observation. It is possible that when Ro 10-9359 arrested cell proliferation by $50-60 \%$, the cells that did divide produced progeny that expressed only a part of the differentiation program.

The keratohyalin granule protein fraction contains histidine rich proteins; some of these continue to become, by a process of dephosphorylation, stratum corneum basic protein (filaggrin) [28]. The progeny of the Ro 10-9359 treated cells might be expressing a different program, i.e., these proteins are being synthesized but not processed properly so that they accumulate in this fraction. Alternatively, this retinoid might be stimulating the production of keratohyalin granule macroaggregated proteins by a smaller popu- 
lation of differentiating cells. Whatever the case, the Ro 10-9359 ans 13-cis retinoic acid analogs had opposite effects on this aspect of epidermal keratinocyte differentiation.

A number of studies have reported both reciprocal and a concordant control of these two keratinocyte functions. Green reported that arresting basal cell proliferation by suspending the cells in medium containing methyl cellulose (an inhibitory effect on growth) led to terminal differentiation [26]. Hennings and coworkers [29] have also reported inverse expression of these functions. When keratinocyte cultures are grown in low to moderate calcium the cells go into a state of accelerated proliferation. These cells do not stratify or form desmosomal complexes, and corneum-related protein and keratin protein synthesis is also affected $[29,30]$. Our studies on epidermal keratinocyte growth regulation have shown that cyclic AMP, which is an epidermal mitogen, stimulated the cells to produce a greater number of differentiating keratinocytes [31,32]; thus proliferation and differentiation are concordantly induced by this cyclic nucleotide. Additionally, the data presented in this report describes another example of concordant expression of growth control, i.e., proliferation and differentiation were both inhibited by the retinoids.

Thus, our work and that of a number of investigators working in the area of epidermal keratinocyte function indicate that proliferation and differentiation can be both reciprocally and concordantly expressed in the epidermis. The available data suggests that in vitro basal cell proliferation, and the production of a differentiating cell population can be regulated by a number of agents, i.e., cyclic nucleotides, vitamin A analogs and calcium, and that each agent or change may produce a unique effect on the balance between these two epidermal keratinocyte functions.

Acknowledgements. We would like to thank Mr. Robert Gold for the electron micrographs and Mrs. Lenore Rhodes for technical assistance. This work was supported by NIH grant R01 AM 26009.

\section{References}

1. Inversen OH, Bjerknes R, Devik F (1968) Kinetics of cell renewal, cell migration and cell loss in the hairless mouse dorsal epidermis. Tissue Kinet $1: 351-367$

2. Voorhees JJ, Duell EA (1975) Imbalanced cyclic AMP-cyclic GMP levels in psoriasis. In: Drummond GI, Greengard P, Robison GA (eds) Advances in cyclic nucleotide research, vol 5. Raven Press Books Ltd, New York, pp 735-758

3. Hicks R (1969) Nature of the keratohyalin-like granules in hyperplastic and cornified areas of transitional epithelium in the vitamin A-deficient rat. J Invest Anat 104:327-339

4. Logan WS (1972) Vitamin A and keratinization. Arch Dermatol $105: 748-753$
5. Hardy MH, Sweeny PR, Bellows CG (1978) The effects of vitamin $A$ on the epidermis of the fetal mouse in organ culture-an ultrastructural study. J Ultrastruct Res 64:246-260

6. Tsambaos D, Marhle G, Orfanos C (1980) Epidermal changes induced by oral excess of aromatic retinoid in guinea pigs. Arch Dermatol Res 267:141-152

7. Aoyagi T, Kamigaki K, Saruta M, Iizuka H, Miura Y (1981) Retinoid inhibits keratin formation of pig skin explants. J Dermatol 8:207-- 213

8. Yaar M, Stanley JR, Katz SI (1981) Retinoic acid delays the terminal differentiation of keratinocytes in suspension culture. J Invest Dermatol 76:363-366

9. Milstone LM, McGuire J, LaVigne JF (1982) Retinoic acid causes premature desquamation of cells from confluent cultures of stratified squamous epithelia. J Invest Dermatol $79: 253-260$

10. McGuire J, Fedarko N, Johanssen E, LaVigne J, Lyons G, Milstone L, Osber M (1982) The influence of retinoids on cultivated human keratinocytes. Am Acad Dermatol 6 (part 2): $630-639$

11. Mahrle G, Gray B (1983) Effect of vitamin A acid on homeostasis and differentiation of epidermal cells cultured on collagen. Dermatologica 166:192-198

12. Christopher E (1974) Growth stimulation of cultured postembryonic epidermal cells by vitamin A acid. J Invest Dermatol $63: 450-455$

13. Wilkinson D (1978) Effect of vitamin A acid on the growth of keratinocytes in culture. Arch Dermatol Res 263:75-81

14. Mahrle GO, Wilkinson DI, Farber EM (1981) Effects of retinoids on keratinocytes in vitro. In: Orfanos CE et al. (eds) Retinoids: Advances in basic research and therapy. Springer, Berlin Heidelberg New York, pp 145-152

15. Pohl J, Christophers E (1981) Mitogenic properties of aromatic retinoids: in vivo and in vitro effects on epidermal cells. In: Orfanos CE et al. (eds) Retinoids: Advances in basic research and therapy. Springer, Berlin Heidelberg New York, pp 133-143

16. Orfanos CE et al. (eds) (1981) Retinoids: Advances in basic research and therapy. Springer, Berlin Heidelberg New York

17. Marcelo CL, Kim YG, Kaine JL, Voorhees JJ (1978) Stratification, specialization, and proliferation of primary keratinocyte cultures. J Cell Biol 79:356-370

18. Marcelo CL, Tong PSL (1983) Epidermal cell growth: Changes in protein composition, synthesis and keratins in differentiating cultures. J Invest Dermatol 80:37-44

19. Steinert PM (1975) The extraction and characterization of bovine epidermal $\alpha$-keratin. Biochem J 149:39-48

20. Laemmli UK (1970) Cleavage of structural proteins during the assembly of the head of bacteriophase $\mathrm{T}_{4}$. Nature 227:680-685

21. Nadal-Ginard B (1978) Commitment, fusion and biochemical differentiation of a myogenic cell line in the absence of DNA synthesis. Cell 15:855-864

22. Scott RE, Florine DL, Willie JJ, Yun K (1982) Coupling of growth arrest and differentiation at a distince state in the $G_{1}$ phase of the cell cycle: $G_{D}$. Proc Natl Acad Sci USA 79:845-849

23. Newton DL, Henderson WR, Sporn MB (1980) Structureactivity relationships of retinoids in hamster tracheal organ culture. Cancer Res 40:3413-3425

24. Haddox MK, Russell DH (1979) Cell cycle-specific locus of vitamin A inhibition of growth. Cancer Res 39:2476-2480

25. Dion LD, Gifford GE (1980) Retinoic acid induces a $G_{1}$ cell cycle block in HeLa cells. Proc Soc Exp Biol Med 163:510 - 514

26. Green H (1977) Terminal differentiation of cultured human epidermal cells. Cell 11:405-416

27. Fuchs E, Green H (1981) Regulation of terminal differentiation of cultured keratinocytes by Vitamin A. Cell 25:617-625

28. Lonsdale-Eccles J, Haugen J, Dale D (1980) A phosphorylated keratohyalin-derived precursor of epidermal stratum corneum basic protein. J Biol Chem 225:2235-2238 
29. Hennings H, Michael D, Cheng C, Steinert P, Holbrook K, Yuspa $S$ (1980) Calcium regulation of growth and differentiation of mouse epidermal cells in culture. Cell $19: 245-254$

30. Marcelo CL, Gold R (1983) Decreases in keratins and cell envelopes, and increases in keratohyalin proteins occur in low calcium regulated keratinocytes. Clin Res:585A

31. Marcelo CL (1979) Differential effects of cAMP and cGMP on in vitro epidermal cell growth. Exp Cell Res 120:201-210

32. Tong PS, Marcelo CL (1983) Augmentation of keratinocyte differentiation by the epidermal mitogen, 8-BrcAMP. Exp Cell Res (in press)
33. Madison K, Tong PS, Marcelo CL, Voorhees JJ (1981) Ro 109359 retinoid inhibits both in vitro epidermal cell proliferation and differentiation. In: Orfanos CE, Braun-Falco O, Farber E, Grupper C, Polano M, Schuppli R (eds) Retinoids. Springer, Berlin Heidelberg New York, p 161

Received February 14, 1983 